\title{
IL-13 Modulates Interferon-mediated ACE2 Expression in Upper Airway Epithelial Cells
}

Syed Khalil ${ }^{1}$, Heather Kulaga ${ }^{1}$, Naina Gour ${ }^{2}$, Stephane Lajoie ${ }^{1}$, and Andrew P. Lane ${ }^{3}$

${ }^{1}$ Johns Hopkins University

${ }^{2}$ Johns Hopkins School of Medicine

${ }^{3}$ Johns Hopkins Univ

July 15, 2020

\section{Hosted file}

Khalil ACE2_Allergy LTE_Final.pdf available at https://authorea.com/users/343007/articles/ 469732-il-13-modulates-interferon-mediated-ace2-expression-in-upper-airway-epithelialcells

Figure 1
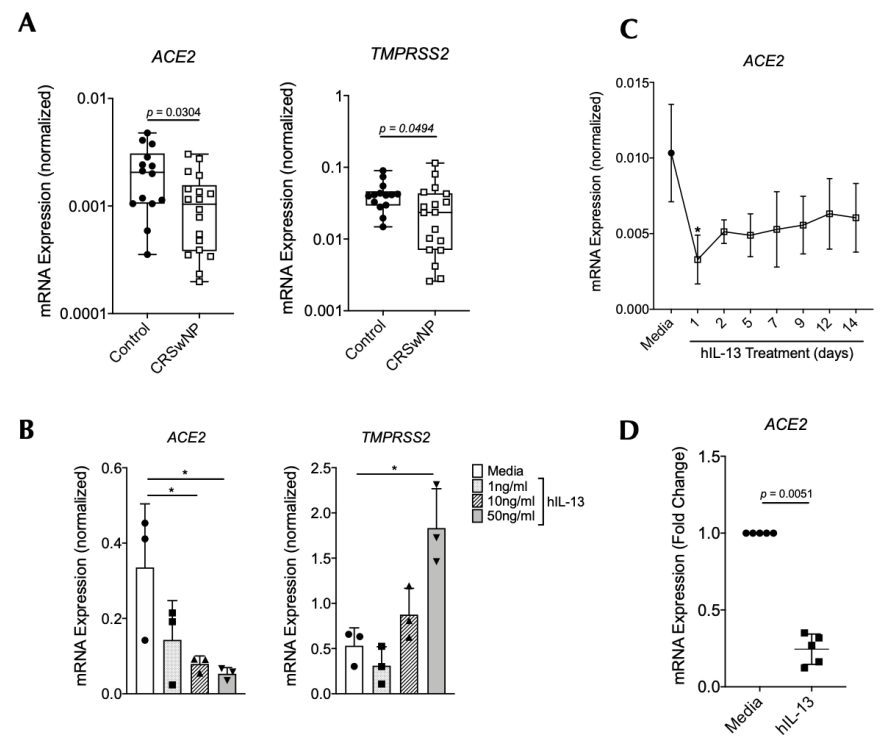
Figure 2

A

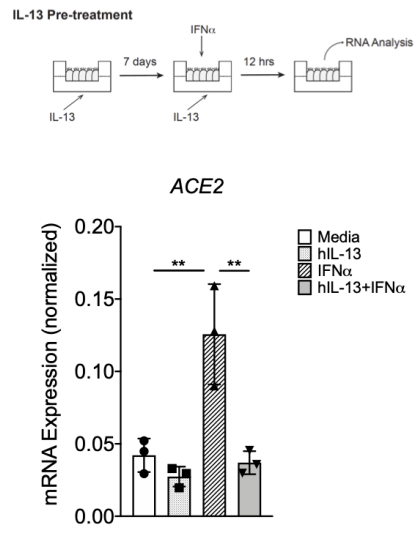

B

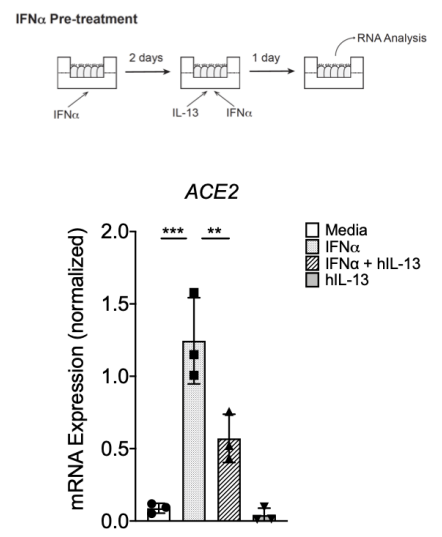

